\title{
PROCEEDINGS OF THE ASSOCIATION OF INDUSTRIAL MEDICAL OFFICERS
}

\section{THIRTY-EIGHTH MEETING}

The thirty-eighth meeting of the Association was held in Birmingham on January 25 and 26, 1945. The meeting on January 25 was concerned with private business (reported below). On January 26 , in the morning, visits were paid to various iron foundries in the Midlands through the courtesy of a number of employers. In the afternoon a film was shown and papers read on health in foundries (v.i.) at the Birmingham Accident Hospital. In the evening the Association held a dinner, the first since September 1939, at the White Horse Hotel. The principal guest was Dr. R. E. Priestley, Vice-Chancellor of Birmingham University.

\section{Business Meeting, Queen's Hotel}

In opening the meeting on Thursday, January 25 , the chairman, Dr. J. C. Bridge, thanked the Birmingham Group for inviting the Association to hold this meeting in their city, and for making the necessary difficult arrangements. It was particularly fortunate that, once again, the Association had been able to arrange a dinner. This said much for the catering potential of the Midlands.

Representatives on Outside Bodies.-Drs. N. T. Glynn (Birmingham) and C. L. Potts (Redditch) were elected to represent the Association on the British Council for Rehabilitation.

Drs. J. C. Bridge (London) and P. Pringle (London) were elected to serve on a committee of the Central Council for Health Education concerned with propaganda relating to the care of the feet. This committee had been set up at the request of the Minister of Health.

B.M.A. Committee on' Charter for Health.-It was reported that the Council of the British Medical Association had formed a committee to prepare for the information of the public a statement of the profession's views and suggestions on such important matters as housing, nutrition, occupation, health education, and leisure. Dr. N. T. Glynn (Birmingham) had been invited by the Council to serve on this committee as the representative of industrial medicine. He made a short statement outlining the constitution of the committee and the preliminary work it had accomplished. He himself had been asked to submit a memorandum on occupation in relation to health. Points he proposed to cover included full employment, adequate pay, the worker's suitability for his job, conditions at work, the aims of an industrial health service, welfare services, hours of work, holidays, canteens, and the journey to work.

War-Time Rest Breaks Scheme.-The following resolution proposed by Dr. J. G. Billington (Birmingham) and seconded by Dr. Alice Peters (Ministry of Supply) was unanimously agreed-

“ The Association of Industrial Medical Officers realise and appreciate the good work that has been and is being done by the War-Time Rest Breaks Scheme for industrial workers in preventing illness and breakdown and in restoring workers to full health. The Association considers that the Scheme is worthy of continual support and steady

The Honorary Secretary was instructed to send a copy of the resolution to the Secretary of the National Committee of the Scheme.

Registration of Specialists.-The chairman reported that he had been in communication with the Registrar of the General Council of Medical Education and Registration of the United Kingdom. He wished to find out something of the position of industrial medical officers in relation to the proposed registration of specialists. He had been informed that as the law stands at present the Council has no power to designate any registered medical practitioner as a specialist in the medical register; but in the event of fresh legislation every practitioner should have at least the right to apply for registration as a specialist.

Foreign Relations Committee.-Dr. Pringle proposed the re-formation of the Association's committee on foreign relations. It was now an opportune time to explore the possibility of opening relations with similar Associations to our own in foreign countries. The matter was referred to the Executive Committee.

\section{Health of Foundry Workers}

On Friday, January 26, in the gymnasium of the Birmingham Accident Hospital, a discussion on this subject was opened by Mr. FitzHerbert Wright, Chairman of the Council of Iron Foundry Associations, who also showed a film on the work done in iron foundries. He was followed by Dr. G. F. Keatinge (Nottingham).

Mr. FitzHerbert Wright said that the casting of metal of all sorts, including gold and silver, had been carried out for ages. Iroh itself was first worked as wrought iron and only later came to be cast. This opened up a tremendous field in the engineering world. Steam came along after and still further opened the floodgates of development in the foundry industry, followed by electricity and the internal combustion engine. In more recent years still, the foundry has spread its wings and entered on new fields such as the casting of steel, aluminium, brass, and the light alloys. However, the oldest application was iron which is still the most important of them all, because of its inherent stability and, to a certain extent, its cheapness of production.

Iron castings in some way or other are the basis of almost everything we use. At present there are about 1,750 iron foundries in this country; iron is responsible by weight for 2.5 million tons and steel for about 350,000 tons annually. The post-war demand is going to be greater, largely owing to the curtailment of civilian goods during the war, and an output of 3 to $3 \frac{1}{2}$ millions will be required. There are problems to be solved here, the most important one being labour. The foundry has, in the past, been an unattractive place to work in; dirty, and probably badly ventilated as well. This is where doctors can help, and the organized part of the industry is also doing its best to see that conditions are improved. Rates of pay are not bad, but in general youth does not as yet find attractive the prospect of a career in a foundry. An interesting book published by the Council of Iron Foundry Associations will shortly be available to show what a foundryman's life is like and will also show the educational facilities industry is putting forward and the big jobs that there are to be had. Dr. Keatinge will be dealing with special problems such as ventilation, heating and dusts, but by and large the foundry is not an unhealthy place in which to work.

The main processes in any foundry are: (1) melting of the metal; (2) preparation of the pattern; (3) preparation of the material which is to receive the metal-the moulds; (4) preparation of the material for the core and the making thereof; (5) pouring metal into the mould; (6) stripping and cleaning of fettling of the casting thereafter.

Careful control is required all the way through the 
process if a good casting is to be achieved, not only of the metal but the sand or chills or permanent mould, whichever is to be used. Owing to the idiosyncrasies of draughtsmen and engineers, there will always be a field for jobbing foundries. Every designer who puts pencil to paper produces a new casting to suit his fancy. These appear all too often mere figments of an engineer's brain: they may be queer castings of which only one or two may be required. No proper equipment can be put in hand for the job and the success of it depends largely on the moulder's skill, in loam moulding especially. Fewer and fewer young moulders are coming on, and a great deal of standardization in the engineer's mind will have to take place if he still wants to obtain efficient castings. When a machine has to be mass-produced proper pattern equipment can be provided, the job can go into a mechanized foundry, and people can work with laboursaving plant. The plant can be worked by unskilled and semi-skilled people. This means a great deal of planning beforehand and careful control all the way through the process. In other words, a few highlyskilled technical men plan the job, produce designs and patterns, and provide the necessary supervision, the mass of work being carried through by their lesser skilled brothers. Industry is gradually developing on these lines, and this must increase more in this country if we are to survive. Our birth rate is falling, there are fewer pairs of hands, and our technical men must plan more and more for saving labour and time. So those who are the semi-skilled will then work under less arduous conditions and have shorter hours. They will be able to produce the same output in these shorter hours; and with more time for recreation they can then improve their minds and bodies, and so do much to relieve the monotony of their jobs. All this is a year or two ahead perhaps but it is certain to come.

\section{BIRMINGHAM GROUP}

At a meeting on January 16 th, Dr. E. H. Capel was elected honorary secretary of the group for 1945. Dr. Jean Mackintosh, senior assistant M.O.H., opened a discussion on 'Health Propaganda in Factories.'

Recently the Birmingham City Council had been considering the development of health education among adults, including post-school juveniles, and appointed a special sub-committee of the Health Committee to deal with the matter. The general range of work has been planned to include instruction in nutrition; personal and communal hygiene, including infectious and contagious disease and V.D.; the principles of healthy living, including sleep, rest, exercise, and the physiology of sex and child care and parentcraft. A programme of this kind should have value and interest for factory personnel. It is felt that health propaganda in the factory should not be limited only to minimizing the hazards of work, bu that it should be extended to include all aspects of health education. It is obvious that the worker's efficiency is influenced not only by the environmental conditions in the factory and his conduct while there, but also by the food he eats, by his home environment and the way he occupies his time when he is not at work in the factory. It is also desirable that he should have some knowledge of what the community does, to assist him in ways of healthy living. Some factory medical officers may fee that they themselves can cover the whole of this work, but there are no doubt others who would be glad to receive assistance from outside.

It was with a view to exploring the possibilities and arriving at some estimate of the need that Dr. Mackintosh sought an opportunity of meeting industrial medical officers working in this area.

\section{NOTTINGHAM GROUP}

At a meeting on November 30,1944 , Dr. A. I. G McLaughlin gave a demonstration of films and histological preparations of pneumokoniosis occurring in foundry workers. Films were shown demonstrating asbestosis and silicosis in various trades, pneumokoniosis of steel workers and coal miners, steel and iron foundry workers and sand moulders. Films were also shown of workers inhaling iron oxide in various occupations, to show the opacity of iron oxide to x-rays.

Dr. McLaughlin said that originally the word pneumokoniosis was used for lung diseases caused by dust There were subdivisions, such as anthracosis, siderosis and silicosis to denote the dust concerned, i.e. coal, iron and silica respectively, but no distinction in their effects was recognized. Gradually it became apparen that one dust, silica, was far more injurious than others, and finally it was realized that when other dusts had apparently produced lung disease, this was due to the effects of silica in the dusts. Silicosis and asbestosis are probably the only true pneumokonioses, because the dusts of free silica $\left(\mathrm{SiO}_{2}\right)$ and asbestos both produce fibrosis of the lung. As far as is known, other dusts do not produce fibrosis. Silicosis is caused by breathing air containing the dust of free silica. It is characterized anatomically by generalized fibrotic changes and the development of miliary nodulation in both lungs, and clinically by shortness of breath, decreased chest expansion, lessened capacity for work, absence of fever, increased susceptibility to tuberculosis and by characteristic $\mathrm{x}$-ray changes. Asbestosis is caused by the dust of asbestos, the only silicate known to cause fibrosis of the lungs. Physical signs are usually those of a basal fibrosis. Asbestos fibres are not easily ingested by dust cells and removed to lymphoid tissue, but remain in contact with the air spaces and set up a fibrosis which begins about the terminal bronchioles. Silico-anthracosis is due to deposits of mixed dusts containing coal and free silica in similar positions. A definite fibrosis develops as in silicosis. The term siderosis should not denote fibrosis of the lungs due to iron dust. Pure iron oxide does not set up a fibrotic reaction. Fibrosis may occur when the iron dust is mixed with silica and the condition may then be known as siderofibrosis (as in fibrosis of boiler scalers). All dusts inhaled and retained in the lungs of workers are deposited in the lymph channels and stations-usually peribronchial, perivascular, glandular and subpleural. This accounts for similarity of $\mathrm{x}$-ray appearances in the dust pneumokonioses. In some cases abnormal $\mathrm{x}$-ray shadows are thrown by areas of fibrosis and congestion, in others the shadows are due to the fact that the dust aggregates are opaque to x-rays. Opacity to $\mathrm{x}$-rays depends on the atomic weight of the element.

A meeting took place on January 11, 1945. Dr. J. C. Bridge took the chair on the invitation of the group chairman, Dr. T. A. Lloyd Davies. A description of the R.A.F. Rehabilitation Unit was given by Group Captain C. J. S. O'Malley and Squadron-Leader Zinovieff, who were introduced to the meeting by Dr. Bridge. Group Captain O'Malley sketched the development of surgical rehabilitation in this country, paying tribute to the work of such pioneers as the late Sir Robert Jones, Harold E. Moore, Alexander Miller, H. E. Griffiths and E. A. Nicoll. The first beginnings of the R.A.F. Rehabilitation Unit were at the R.A.F. Officers' Hospital, Torquay, in 1940 and centres for other ranks were at Hoylake and Blackpool. When the hospital at Torquay was bombed and most of the skilled personnel were lost, a Unit was formed at Loughborough. Rehabilitation should start in hospital and finish at the rehabilitation centre, the atmosphere of which should inculcate the will to get better; the body-mind needed treatment; in fact the injured person should be dealt with as a whole. The Loughborough Rehabilitation Centre is not a hospital; it is run largely as a club with a benevolent autocracy at the top. It is important that the environment should be of a kind to which the man is accustomed. Cases arrive at the unit as soon as they are fit to move from hospital: fractures, when the patient is in an unpadded plaster; and soft tissue injuries, when the stitches have been removed. Great importance is attached to the reception of the patient who is made to feel at home from the first moment of arrival. 
Elimination of self-pity is the primary principle, and in order to do this excessive sympathy with the man is avoided. Boredom and monotony are removed by evening programmes, such as films, dances, debates following talks by well known public people, and talks by the patients themselves on any subject they please for twenty minutes. Many of the patients are frightened to get well because this will involve a return to the environment which caused the trouble. This is especially true of the officer air crew; so pilots, observers, gunners and wireless operators are all given their own kind of work to do as soon as fit for it. Thus pilots use the Link Trainer, air gunners use power-operated turrets and also the rifle range and they are encouraged in clay pigeon shooting. Fitters work on the actual machines on which work will subsequently be done, e.g. the air frame fitter works on an actual fuselage. Occupational therapy is given to those not yet fit to undertake more advanced work. Clay modelling is useful for burnt hands. Weaving is not used as it is completely divorced from reality. An actual factory at which men work is established at East Grinstead in which a time study of programme of work was given as 40,000 hours. The work was actually performed by these injured men in 19,000 hours. Ninety-two per cent. of officers passing through the unit went back to flying duties and 64 per cent. to operational flying. Eighty-four per cent. of other ranks went back to their trades.

Squadron-Leader Zinovieff stated that everything possible is done to ensure the co-operation of the patient. Thus the objective to be achieved is explained to him and the patient is personally introduced to the physiotherapist or PT instructor who would be treating the case. Physiotherapy is important but should not be made to appear so to the patient. Active movements on his own part are much more important. In order to emphasize this point of view the physiotherapy department is known as the Early Mobilisation Room. There is continuous supervision by the medical officers of the actual treatment of patients. The programme is varied so as to prevent boredom and arranged so as to suit each individual problem. The treatment depends on the working of the medical personnel of the team; the medical officer gets to know each patient intimately and the physiotherapists and PT instructors are taught the proper approach to the patient and provide a routine report on their cases weekly. Every member of the team requires to have a suitable personality. A PT officer acts as liaison between the medical and PT departments. In general the early cases are treated by physiotherapists aided by rehabilitation orderlies; in the intermediate stage, partly by physiotherapists and partly by PT instructors, and in the advanced stages by PT instructors only. A swimming bath is an essential feature of a rehabilitation centre for swimming constitutes the best non-weight bearing exercise there is. Cases are divided into anatomical groups: (1) Armsshoulders, elbows, wrists, hands; (2) Legs-femur, ankles and feet, tibia and fibula, knee joints; (3) Spines, and (4) Multiple injuries. A very complete dossier of each patient's case comes to the centre from the hospita where he was treated and in it are full notes and reduced prints of x-rays relevant to the case. Notes are kept at the rehabilitation unit and a secretary is needed for this work so that the medical officer can devote to the patients the time that he would otherwise spend in clerical work.

\section{SCOTTISH GROUP}

At a meeting held at the University of Glasgow on January 24, 1944, with Dr. Harry M. Roberts in the chair, Professor T. Ferguson read a paper on "The Resettlement of Disabled Persons in Industry.

Many factors influence the successful resettlement in work of disabled men. The attitude of employers is important, and especially of their foremen, who can do so much to make or mar success: so too is the attitude of work-mates-who sometimes grow weary of the little extra help that may make all the difference-and the attitude and adaptability of the disabled men themselves. The problems raised by compensation in cases of injury are often a hindrance to resettlement. Again, light work within the industry in which a disabled man was employed prior to his incapacity may be a legitimate, and indeed the most satisfactory, method of restoring him to full fitness for work, but safeguards are necessary to prevent abuse of light work in this connexion and to see that the man is not allowed to drift along indefinitely in light work if he is, in fact, able to do something better. The future of the severely disabled man is so much in the balance that anything that makes him even a little more efficient adds enormously to his prospect of successful resettlement: it is therefore important to secure the highest possible measure of physical and psychological repair. Generally speaking, the longer disability has been present the less satisfactory the prognosis; and age, too, is important. Experience in Denmark has been to the effect that it is rarely an economic proposition to embark on the training in new work of a disabled man over the age of 35 years and recent experience in this country certainly confirms that, in general, younger men do best in relation to training for new employment. The care of the disabled should be set afoot as early as possible and the notification experience of Denmark is worthy of further study.

Geographical considerations may be weighty. Sometimes the nature of the district in which the disabled man lives does not offer much scope for new employment either because of the unrelieved heavy industry in it or because of isolated situation with limited facilities for employment. In Scotland, it is not easy to find suitable work for disabled men in some areas of Lanarkshire. or in some of the more remote parts of the Highlands. The previous industrial experience of the disabled man is of great importance and so is the possibility of harnessing such industrial knowledge or background as he may have to new work. For instance, a man may be unable to follow his trade as a woodworker, but if he can be given a certain amount of commercial training and this related to his basic knowledge of the woodworking industry, then he may become a very valuable agent, despite his disability. In the presence of serious disability it is often of substantial help to secure the return of the disabled man to an industrial environment with which he is familiar; if possible, even to the factory in which he was formerly employed.

Disabled men encounter many difficulties, with medical, social, and employment aspects closely interwoven. Some find their work too heavy; some that long travelling to and from work after a long working shift is too much for them; some have difficulty in obtaining tools; some have difficulty in obtaining suitable clothing. Many have financial troubles; the wages they are able to earn are often too low for their responsibilities. Many chafe at what they think are irksome pension delays. Many have difficulty in getting a suitable house: a disabled man may have almost as much difficulty in making his way up and down the stairs of a high tenement house as in doing his day's work. To be successful the approach to the problems of disability must be along individual lines, and the disabled man must be kept in view until it is clearly established that he is indeed settled in work within his compass. 